\title{
Reactivity of stabilized Criegee intermediates (sCIs) from isoprene and monoterpene ozonolysis toward $\mathrm{SO}_{2}$ and organic acids
}

\author{
M. Sipilä ${ }^{1}$, T. Jokinen ${ }^{1,2}$, T. Berndt ${ }^{2}$, S. Richters ${ }^{2}$, R. Makkonen ${ }^{1,3}$, N. M. Donahue ${ }^{4}$, R. L. Mauldin III ${ }^{1,5,6}$, \\ T. Kurtén ${ }^{7}$, P. Paasonen ${ }^{1}$, N. Sarnela ${ }^{1}$, M. Ehn ${ }^{1}$, H. Junninen ${ }^{1}$, M. P. Rissanen ${ }^{1}$, J. Thornton ${ }^{1}$, F. Stratmann ${ }^{2}$, \\ H. Herrmann ${ }^{1,8,9}$, D. R. Worsnop ${ }^{1}$, M. Kulmala ${ }^{1}$, V.-M. Kerminen ${ }^{1}$, and T. Petäjä ${ }^{1}$ \\ ${ }^{1}$ Department of Physics, University of Helsinki, 00014 Helsinki, Finland \\ ${ }^{2}$ Leibniz Institute for Tropospheric Research, TROPOS, 04318 Leipzig, Germany \\ ${ }^{3}$ Department of Geosciences, University of Oslo, 0316 Oslo, Norway \\ ${ }^{4}$ Center for Atmospheric Particle Studies, Carnegie-Mellon University, Pittsburgh, PA 15213, USA \\ ${ }^{5}$ Department of Atmospheric and Oceanic Sciences University of Colorado - Boulder, Boulder, Colorado 80309, USA \\ ${ }^{6}$ Institute for Arctic and Alpine Research, University of Colorado - Boulder, Boulder, Colorado 80309, USA \\ ${ }^{7}$ Department of Chemistry, University of Helsinki, 00014 Helsinki, Finland \\ ${ }^{8}$ Department of Applied Physics, University of Eastern Finland, 70211 Kuopio, Finland \\ ${ }^{9}$ Aerodyne Research Inc., Billerica, Massachusetts 01821, USA
}

Correspondence to: M. Sipilä (mikko.sipila@helsinki.fi)

Received: 5 December 2013 - Published in Atmos. Chem. Phys. Discuss.: 29 January 2014

Revised: 30 September 2014 - Accepted: 1 October 2014 - Published: 19 November 2014

\begin{abstract}
Oxidation processes in Earth's atmosphere are tightly connected to many environmental and human health issues and are essential drivers for biogeochemistry. Until the recent discovery of the atmospheric relevance of the reaction of stabilized Criegee intermediates (sCIs) with $\mathrm{SO}_{2}$, atmospheric oxidation processes were thought to be dominated by a few main oxidants: ozone, hydroxyl radicals $(\mathrm{OH})$, nitrate radicals and, e.g. over oceans, halogen atoms such as chlorine. Here, we report results from laboratory experiments at $293 \mathrm{~K}$ and atmospheric pressure focusing on sCI formation from the ozonolysis of isoprene and the most abundant monoterpenes ( $\alpha$-pinene and limonene), and subsequent reactions of the resulting sCIs with $\mathrm{SO}_{2}$ producing sulfuric acid $\left(\mathrm{H}_{2} \mathrm{SO}_{4}\right)$. The measured total sCI yields were $(0.15 \pm 0.07),(0.27 \pm 0.12)$ and $(0.58 \pm 0.26)$ for $\alpha$-pinene, limonene and isoprene, respectively. The ratio between the rate coefficient for the sCI loss (including thermal decomposition and the reaction with water vapour) and the rate coefficient for the reaction of sCI with $\mathrm{SO}_{2}$, $k(\mathrm{loss}) / k\left(\mathrm{sCI}+\mathrm{SO}_{2}\right)$, was determined at relative humidities of 10 and $50 \%$. Observed values represent the average reactivity of all sCIs produced from the individual alkene used in the ozonolysis. For the monoterpene-derived sCIs, the rela-
\end{abstract}

tive rate coefficients $k$ (loss) $/ k\left(\mathrm{sCI}+\mathrm{SO}_{2}\right)$ were in the range $(2.0-2.4) \times 10^{12}$ molecules $\mathrm{cm}^{-3}$ and nearly independent of the relative humidity. This fact points to a minor importance of the $\mathrm{sCI}+\mathrm{H}_{2} \mathrm{O}$ reaction in the case of the $\mathrm{sCI}$ arising from $\alpha$-pinene and limonene. For the isoprene sCIs, however, the ratio $k$ (loss) $/ k\left(\mathrm{sCI}+\mathrm{SO}_{2}\right)$ was strongly dependent on the relative humidity. To explore whether sCIs could have a more general role in atmospheric oxidation, we investigated as an example the reactivity of acetone oxide ( $\mathrm{sCI}$ from the ozonolysis of 2,3-dimethyl-2-butene) toward small organic acids, i.e. formic and acetic acid. Acetone oxide was found to react faster with the organic acids than with $\mathrm{SO}_{2}$; $k(\mathrm{sCI}+\mathrm{acid}) / k\left(\mathrm{sCI}+\mathrm{SO}_{2}\right)=(2.8 \pm 0.3)$ for formic acid, and $k(\mathrm{sCI}+\mathrm{acid}) / k\left(\mathrm{sCI}+\mathrm{SO}_{2}\right)=(3.4 \pm 0.2)$ for acetic acid. This finding indicates that $\mathrm{sCIs}$ can play a role in the formation and loss of other atmospheric constituents besides $\mathrm{SO}_{2}$.

\section{Introduction}

Ozone, hydroxyl radicals $(\mathrm{OH})$ and nitrate radicals and halogens atoms can initiate the oxidation of hydrocarbons such 
as biogenic terpenes in the atmosphere (Atkinson, 2000). Although the reactivity of these oxidants toward a large variety of atmospheric trace gases is well established, ambient observations have revealed major ambiguities in atmospheric oxidation chemistry, especially related to $\mathrm{OH}$ in locations having high emissions of biogenic volatile organic compounds (BVOCs) (Di Carlo et al., 2004; Lou et al., 2010; Nölscher et al., 2012; Lelieveld et al., 2008; Hofzumahaus et al., 2009; Taraborrelli, et al., 2012). Recently, two additional major processes contributing to the complexity of atmospheric oxidation have been revealed: firstly, the autooxidation mechanism producing highly oxidized condensable organic vapours in the gas phase discovered by Ehn et al. (2014) - such vapours are shown to be essential for formation of secondary organic aerosol (Kulmala et al., 1998; Riipinen et al., 2011); secondly, the suggestion that stabilized Criegee intermediates (sCIs), formed by ozonolysis of biogenic alkenes (Criegee, 1975), might add to the oxidation capacity of the atmosphere - at least from the point of view of $\mathrm{SO}_{2}$ oxidation and subsequent formation of sulfuric acid, $\mathrm{H}_{2} \mathrm{SO}_{4}$ (Mauldin III et al., 2012; Berndt et al., 2012; Welz et al., 2012). These findings demonstrate the incomplete scientific understanding of atmospheric oxidation chemistry. Here, we focus on the latter of those novel observations.

The sCI formation pathway starts when ozone reacts with the double bond of an alkene, producing an energy-rich primary ozonide, which very rapidly decomposes via a concerted ring opening to form a carbonyl oxide, the so-called Criegee intermediate (CI) (Calvert et al., 2000). The energyrich intermediate, $\mathrm{CI}$, either undergoes unimolecular decomposition on a timescale of $1 \mathrm{~ns}$, yielding $\mathrm{OH}$ radicals and other products, or it can be stabilized by collisions with gas molecules (Kroll et al., 2001). The resulting sCI can still undergo unimolecular decomposition, leading again to $\mathrm{OH}$ radical formation and others, but with a thermal lifetime thought to be of the order of $1 \mathrm{~s}$ depending on temperature and $\mathrm{sCI}$ structure (Kroll et al., 2001). Due to the relatively long lifetime of sCI, bimolecular reactions of sCIs with several compounds like water vapour, $\mathrm{SO}_{2}$, carbonyls, organic acids, etc., are also possible (e.g. Neeb et al., 1996, 1997; Johnson, 2001; Welz et al., 2012, 2014; Mauldin III et al., 2012; Berndt et al., 2012, 2014a, b; Taatjes et al., 2012, 2013). These reactions can potentially be fast enough to contribute significantly to the atmospheric oxidation capacity. Thus, some significant gaps in our understanding of atmospheric oxidation could potentially be filled by sCI chemistry, once the processes controlling the production and fate of sCIs are properly resolved.

Until recently, the reaction rate coefficients of sCIs with atmospheric compounds, such as $\mathrm{SO}_{2}$, were thought to be too small (Johnson, 2001) to cause measurable effects on atmospheric oxidation chemistry, with the exception of the sCI+ water vapour reactions (Hasson, 2003). The reaction with water vapour was also thought to be the main fate of sCIs in the atmosphere. However, Mauldin III et al. (2012) recently reported ambient and laboratory observations strongly suggesting an atmospherically relevant reaction between $\mathrm{sCI}$ and $\mathrm{SO}_{2}$. This was qualitatively supported by the laboratory experiment of Welz et al. (2012). Welz et al. (2012) studied the simplest possible Criegee intermediate (formaldehyde oxide, $\mathrm{CH}_{2} \mathrm{OO}$ ) in a low-pressure (4 torr) laboratory experiment, finding an absolute rate coefficient for the $\mathrm{CH}_{2} \mathrm{OO}+\mathrm{SO}_{2}$ reaction of $3.9 \times 10^{-11} \mathrm{~cm}^{3}$ molecule ${ }^{-1} \mathrm{~s}^{-1}$. Mauldin III et al. (2012) estimated the reaction rate coefficient to be roughly $6 \times 10^{-13}$ and $8 \times 10^{-13} \mathrm{~cm}^{3}$ molecule ${ }^{-1} \mathrm{~s}^{-1}$ for sCIs from the ozonolysis of $\alpha$-pinene and limonene, respectively. Berndt et al. (2012) investigated experimentally the sCI yields, lifetimes and rate coefficients for reactions with $\mathrm{SO}_{2}$ for sCIs from the ozonolysis of selected alkenes including 2,3-dimethyl-2-butene (TME), trans-2-butene and 1-methyl-cyclohexene $(\mathrm{MCH})$. Using an indirect approach based on $\mathrm{H}_{2} \mathrm{SO}_{4}$ measurements, they found typical lifetimes at atmospheric pressure and an atmospherically relevant humidity of a few hundreds of milliseconds, and reaction rate coefficients for $\mathrm{sCI}+\mathrm{SO}_{2}$ of the order of $10^{-13}-10^{-12} \mathrm{~cm}^{3}$ molecule ${ }^{-1} \mathrm{~s}^{-1}$, depending on the structure of the sCI.

It should be noted that ozonolysis of a single alkene in most cases produces structurally different types of sCI, including syn- and anti-conformers (for sCIs with one $\mathrm{H}$ atom bound at the $\mathrm{C}-\mathrm{OO}$ carbon) which might have a different reactivity. Therefore, the given data for $\alpha$-pinene and limonene (Mauldin III et al., 2012) and for trans-2-butene and 1-methyl-cyclohexene (Berndt et al., 2012) represent average values for the reactivity of all sCIs arising from the selected alkene.

In summary, both the laboratory measurements by Berndt et al. (2012) and field observations by Mauldin III et al. (2012) suggest that SCI are roughly a factor of $\sim 100$ more reactive with $\mathrm{SO}_{2}$ than suggested earlier (Johnson, 2001), but approximately 2 orders of magnitude less reactive than the close-to-collision-limit rate coefficient by Welz et al. (2012). Nevertheless, while recent findings agree on the potential significance of the $\mathrm{sCI}+\mathrm{SO}_{2}$ reaction, there is still a considerable uncertainty in the absolute and relative rate constants obtained by different experimental approaches.

Understanding the reaction of the $\mathrm{sCI}+\mathrm{SO}_{2}$ is highly important from the atmospheric chemistry and physics point of view. Sulfuric acid plays a key role in Earth's atmosphere, triggering secondary aerosol formation (Kulmala et al., 2004; Berndt et al., 2005, Riipinen et al., 2007; Sipilä et al., 2010; Kerminen et al., 2010), and thus connects natural and anthropogenic $\mathrm{SO}_{2}$ emissions to global climate via indirect aerosol effects on radiative forcing. The effect of $\mathrm{sCI}$ on $\mathrm{SO}_{2}$ oxidation was assessed by Boy et al. (2013), who simulated sulfuric acid production at the SMEAR (Station for measuring atmosphere-ecosystem relations) II boreal forest field station using the reaction rate coefficients suggested by Mauldin III et al. (2012). Their results supported the experimental observations by Mauldin III et al. (2012), showing that a signif- 
icant fraction (several tens of percents) of ground-level gas phase sulfuric acid originates probably from sCI-initiated oxidation of $\mathrm{SO}_{2}$. Pierce et al. (2013) took a step further and studied the role of the $\mathrm{sCI}+\mathrm{SO}_{2}$ reaction to global aerosol and cloud condensation nuclei $(\mathrm{CCN})$ concentrations by the global climate model. They found, in accordance with Boy et al. (2013), that sCIs can contribute significantly to gas phase $\mathrm{H}_{2} \mathrm{SO}_{4}$ in the lower troposphere above forested areas. However, due to further aerosol dynamical processes during particle growth to $\mathrm{CCN}$ sizes, the influence of sCI on sulfuric acid concentration was only feebly projected to $\mathrm{CCN}$ concentrations, and thus to radiative forcing. However, Pierce et al. (2013) used reaction rate coefficients, including the upper limit for the sCI loss rate (decomposition and reaction with water vapour), obtained by Welz et al. (2012) for $\mathrm{CH}_{2} \mathrm{OO}$. Furthermore, the sCI reaction rate coefficients, including sCI loss in a reaction with water, may be strongly dependent on the sCI structure. Therefore, a reassessment of the CCN sensitivity, using parameters obtained for atmospherically relevant $\mathrm{sCIs}$ in atmospheric conditions, would be warranted.

On top of the reaction with $\mathrm{SO}_{2}$, a further, mostly unresolved question is whether or not oxidation by $\mathrm{sCI}$ has a more general role in atmospheric chemistry. Earlier studies have probed the reaction of $\mathrm{CH}_{2} \mathrm{OO}$ with several atmospheric constituents (see e.g. Fenske et al., 2000). Reaction of $\mathrm{CH}_{2} \mathrm{OO}$ with formic acid, $\mathrm{HCOOH}$, yielding to production of hydroperoxymethyl formate was demonstrated by Neeb et al. (1995, 1996), with follow-up studies by Thamm et al. (1996) and Hasson et al. (2001b). Neeb et al. (1997) showed that the rate coefficient for the above reaction is relatively large (14000-fold) in comparison to the reaction rate coefficient for $\mathrm{CH}_{2} \mathrm{OO}+$ water. An extremely high reactivity of $\mathrm{CH}_{2} \mathrm{OO}$ and $\mathrm{CH}_{3} \mathrm{CHOO}$ toward formic $(\mathrm{HCOOH})$ and acetic acid $\left(\mathrm{CH}_{3} \mathrm{COOH}\right)$ was observed also by Welz et al. (2014) in a low-pressure system. Also Taatjes et al. (2012; 2013) showed that sCIs - at least the simple sCIs - are reactive toward other trace gases in addition to $\mathrm{SO}_{2}$. These observations imply that reactions of sCI with organic acids might have atmospheric importance, and further research is urgently required.

In the present study, we investigate experimentally the $\mathrm{sCI}$ yield and the rate coefficient ratio $k(\mathrm{loss}) / k\left(\mathrm{sCI}+\mathrm{SO}_{2}\right)$, where the loss coefficient $k$ (loss) incorporates thermal decomposition of $\mathrm{sCI}$ and the reaction with water vapour, $k($ loss $)=k($ dec.$)+k\left(\mathrm{sCI}+\mathrm{H}_{2} \mathrm{O}\right) \cdot\left[\mathrm{H}_{2} \mathrm{O}\right]$. This rate coefficient ratio represents (for different temperatures and water vapour concentrations) the important parameter for understanding the sCI-controlled oxidation of $\mathrm{SO}_{2}$ to $\mathrm{H}_{2} \mathrm{SO}_{4}$ in the atmosphere. This study comprises reactions of sCIs produced from the ozonolysis of isoprene and two monoterpenes abundant in the atmosphere, i.e. $\alpha$-pinene and limonene. To demonstrate the capability of sCIs playing a more general role in atmospheric chemistry, we investigated the reaction of acetone oxide $\left(\left(\mathrm{CH}_{3}\right)_{2} \mathrm{COO}\right.$, the sCI from TME ozonolysis) with small organic acids.

\section{Methods}

\section{1 $\mathrm{NO}_{3}^{-}$-chemical ionization-atmospheric pressure interface-time-of-flight mass spectrometer (NO-CI-APi-TOF)}

$\mathrm{A} \mathrm{NO}_{3}^{-}$-CI-APi-TOF was used in the experiments described here primarily for the detection of sulfuric acid. The $\mathrm{NO}_{3}^{-}$ CI-APi-TOF comprises a specially designed inlet for chemical ionization at ambient pressure (CI) and an atmospheric pressure interface (APi) to couple ions to a time-of-flight mass spectrometer (TOF). The instrument is described in detail by Jokinen et al. (2012), but the CI part of the system will be shortly discussed also here. The APi-TOF is well described elsewhere (Junninen et al., 2010).

The design of the CI inlet is largely based on the original NCAR design (Eisele et al., 1993; Kurtén et al., 2011; Jokinen et al., 2012). Ions are produced in a sheath flow concentric to the sample flow by a $10 \mathrm{MBq} 241 \mathrm{Am}$ radioactive $\alpha$-emitter. Minute quantities of nitric acid vapour are fed into sheath air surrounding the sample inlet flow, resulting in the formation of $\mathrm{NO}_{3}^{-}\left(\mathrm{HNO}_{3}\right)_{n, n=0-2}$ ions. These ions are pushed into the sample flow, entering the ion-molecule interaction tube at the centre line, by means of an electric field. The design is virtually wall-less, and sample wall loss occurs only in the sample inlet tube. The sample flow in the system is $10 \mathrm{lpm}$, and the concentric sheath flow where ions are produced is $20 \mathrm{lpm}$. Sheath gas is air purified with a particle filter and an $\mathrm{SO}_{2}$ scrubber.

Sample ionization in the CI system occurs at atmospheric pressure via proton transfer between nitrate ions and sulfuric acid and subsequent $\mathrm{HSO}_{4}^{-} \cdot \mathrm{HNO}_{3}$ adduct formation:

$\mathrm{H}_{2} \mathrm{SO}_{4}+\mathrm{NO}_{3}^{-} \cdot\left(\mathrm{HNO}_{3}\right)_{n, n=0-2} \rightarrow$
$\mathrm{HSO}_{4}^{-} \cdot \mathrm{HNO}_{3}+n\left(\mathrm{HNO}_{3}\right), n=0-2$.

The chemically ionized sample is drawn inside the mass spectrometer through a critical orifice with a flow rate of $\sim 0.8 \mathrm{lpm}$. The ions are then guided through the differentially pumped APi using quadrupoles and eventually to the TOF for $\mathrm{m} / \mathrm{Q}$ (mass to charge) separation.

A fraction of $\mathrm{HSO}_{4}^{-} \cdot \mathrm{HNO}_{3}$ clusters (Reaction R1) fragment inside the APi-TOF. The sulfuric acid concentration (in molecules $\mathrm{cm}^{-3}$ ) measured with the $\mathrm{NO}_{3}^{-}$-CI-APi-TOF is calculated from the measured ion signals according to

$\left[\mathrm{H}_{2} \mathrm{SO}_{4}\right]=\frac{\mathrm{HSO}_{4}^{-}+\mathrm{H}_{2} \mathrm{SO}_{4} \mathrm{NO}_{3}^{-}}{\mathrm{NO}_{3}^{-}+\mathrm{HNO}_{3} \mathrm{NO}_{3}^{-}+\mathrm{HNO}_{3}\left(\mathrm{HNO}_{3}\right) \mathrm{NO}_{3}^{-}} \times C$,

where $C$ is the calibration coefficient. The detection limit for sulfuric acid monomer is of the order of $10^{4}$ molecules $\mathrm{cm}^{-3}$, and the error in determined sulfuric acid concentration is $\pm 45 \%$ (Berndt et al., 2012). Data were analysed using TofTools software.

Neglected in the analysis based on Eq. (1) is the potential effect of water vapour on ion chemistry and thus on the 
Table 1. Concentrations of alkenes (initial and reacted within the residence time of $39.5 \mathrm{~s}$ ), $\mathrm{OH}$ scavenger and $\mathrm{O}_{3}$, and the reaction rate coefficients used in the experiments.

\begin{tabular}{|c|c|c|c|c|c|}
\hline Alkene & $\begin{array}{l}\text { [Alkene] } \\
\text { molecules } \mathrm{cm}^{-3}\end{array}$ & [Propane] molecules $\mathrm{cm}^{-3}$ & {$\left[\mathrm{O}_{3}\right]$ molecules $\mathrm{cm}^{-3}$} & $\begin{array}{l}k\left(\text { alkene }+\mathrm{O}_{3}\right) \\
\mathrm{cm}^{3} \mathrm{~s}^{-1}\end{array}$ & $\begin{array}{l}\text { Reacted [alkene] } \\
\text { molecules } \mathrm{cm}^{-3}\end{array}$ \\
\hline$\alpha$-Pinene & $8.0 \times 10^{11}$ & $\begin{array}{l}1.64 \times 10^{15} \\
\left(\mathrm{SO}_{2}:(3.2-160) \times 10^{11}\right) \\
8.2 \times 10^{15} \\
\left(\mathrm{SO}_{2}:(1.6-24) \times 10^{13}\right)\end{array}$ & $2.2 \times 10^{11}$ & $1.1 \times 10^{-16}$ & $7.65 \times 10^{8}$ \\
\hline Limonene & $1.6 \times 10^{11}$ & $\begin{array}{l}1.64 \times 10^{15} \\
\left(\mathrm{SO}_{2}:(3.2-160) \times 10^{11}\right) \\
8.2 \times 10^{15} \\
\left(\mathrm{SO}_{2}:(1.6-16) \times 10^{13}\right)\end{array}$ & $2.2 \times 10^{11}$ & $2.5 \times 10^{-16}$ & $3.48 \times 10^{8}$ \\
\hline Isoprene & $1.5 \times 10^{12}$ & $\begin{array}{l}1.64 \times 10^{15} \\
\left(\mathrm{SO}_{2}:(3.2-160) \times 10^{11}\right) \\
8.2 \times 10^{15} \\
\left(\mathrm{SO}_{2}:(1.6-16) \times 10^{13}\right)\end{array}$ & $2.2 \times 10^{11}$ & $1.29 \times 10^{-17}$ & $1.68 \times 10^{8}$ \\
\hline
\end{tabular}

calibration coefficient $C$. Water vapour can affect the level of hydration of sulfuric acid, thereby affecting the charging, the diffusion coefficient and the collision diameter. Nitratewater clusters also have different collision diameter than pure nitrate ions, and clustering could, potentially, change the proton affinity of the primary ions. Also steric effects may play a role. The CI-APi-TOF technique is relatively new, and detailed understanding of how relative humidity (RH) affects the detection does not exist. Experiments on the RHdependent $\mathrm{H}_{2} \mathrm{SO}_{4}$ sensitivity of CI-APi-TOF instruments reveal that the calibration coefficient $C$ is less influenced by $\mathrm{RH}$ in the range $2-65 \%$ and the small changes observed are within the uncertainty of the measurement; see experimental data given in the online discussion of this paper and Berndt et al. (2014a). It is to be noted that the rate coefficient ratios reported here are independent of the absolute $\mathrm{H}_{2} \mathrm{SO}_{4}$ calibration.

\subsection{Laboratory experiments}

Laboratory experiments were conducted in the Leibniz Institute for Tropospheric Research Laminar Flow Tube (IfT-LFT) at $T=293 \pm 0.5 \mathrm{~K}, \quad \mathrm{RH}=10-50 \%$ $\left(\left[\mathrm{H}_{2} \mathrm{O}\right]=(0.58-2.89) \times 10^{17}\right.$ molecules $\left.\mathrm{cm}^{-3}\right)$ and with a flow of $30 \mathrm{lpm}$ (STP) synthetic air as the carrier gas, resulting in a total residence time of $39.5 \mathrm{~s}$. The experimental methods are identical to those reported in Berndt et al. (2014a) but will be described briefly here.

In the experiments focusing on $\mathrm{SCI}$ yields and the relative reaction rate coefficients, the alkenes, $\mathrm{SO}_{2}$ and the $\mathrm{OH}$ radical scavenger (propane) premixed with the humidified carrier gas were fed at the top of the flow tube. Ozone diluted with the carrier gas was introduced through an inlet $55 \mathrm{~cm}$ downstream of the port for the other reactants. The added propane ensured scavenging efficiency of 96.9-99.98\%, de- pending on the experimental conditions, for $\mathrm{OH}$ radicals formed in the ozonolysis. The $\mathrm{SO}_{2}$ concentration was varied in the range $3.2 \times 10^{11}-2.4 \times 10^{14}$ molecules $\mathrm{cm}^{-3}$. Concentrations of alkenes, propane, ozone, the reaction rate coefficients used and the concentration of reacted alkenes within the residence time of $39.5 \mathrm{~s}$ are given in Table 1.

In the experiments focusing on the reactivity of sCI (acetone oxide) toward $\mathrm{HCOOH}$ (formic acid) and $\mathrm{CH}_{3} \mathrm{COOH}$ (acetic acid), with concentrations ranging between $3.0 \times 10^{10}$ and $2.0 \times 10^{13}$ molecules $\mathrm{cm}^{-3}$, were fed together with other reagents at the top of the flow tube. Concentrations of the reagents were (unit: molecules $\mathrm{cm}^{-3}$ ) $[\mathrm{TME}]=4.0 \times 10^{10},\left[\mathrm{O}_{3}\right]=2.2 \times 10^{11},\left[\mathrm{SO}_{2}\right]=3.2 \times 10^{12}$, [propane] $=1.64 \times 10^{15}$ and a relative humidity of $10 \%$.

In all experiments sulfuric acid was measured using the $\mathrm{NO}_{3}^{-}$-CI-APi-TOF and alkene concentrations we measured with the proton transfer reaction mass spectrometer (Ionicon PTR-MS) (Lindinger et al., 1998). The derivation of the parameters of interest from experimental data is described in the Results and discussion section.

\section{Results and discussion}

\section{1 sCI yields and relative rate coefficients}

Figures 1-3 show the sulfuric acid concentration measured at the outflow of IfT-LFT as a function of $\left[\mathrm{SO}_{2}\right]$ at $\mathrm{RH}=10 \%$ and $\mathrm{RH}=50 \%$. In analysing the experimental data the following reaction sequence (Reactions R2-R6) was considered. 


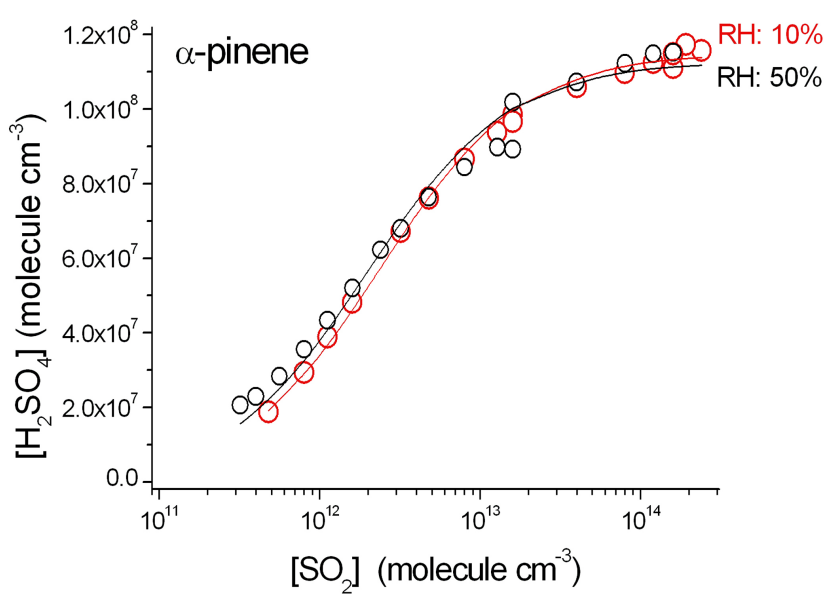

Figure 1. Loss-corrected measured $\left[\mathrm{H}_{2} \mathrm{SO}_{4}\right]$ at the outflow of IfTLFT in $\alpha$-pinene experiments at $\mathrm{RH}=10 \%$ and $\mathrm{RH}=50 \%$. Lines show multivariate least-squares fittings according to Eq. (3), from which the relative rate coefficients and sCI yield were obtained.

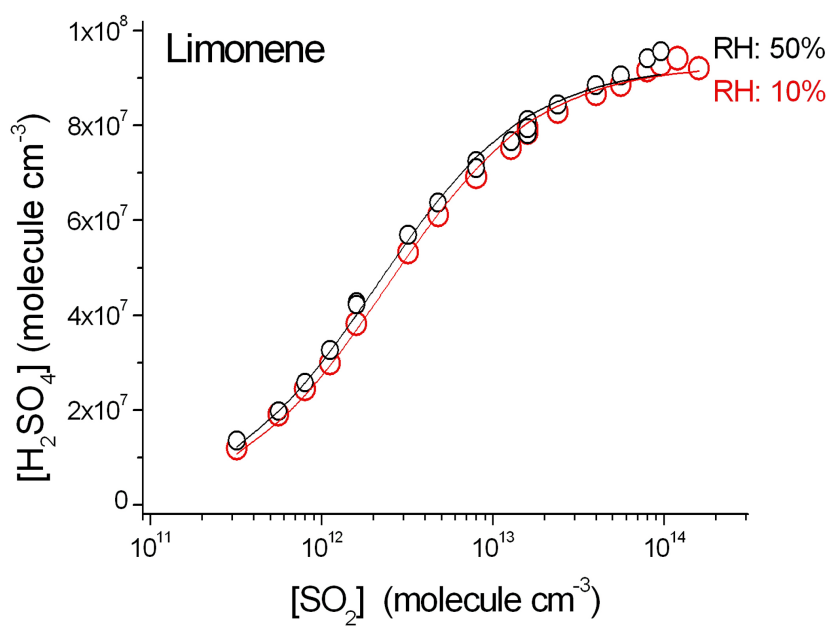

Figure 2. Loss-corrected measured $\left[\mathrm{H}_{2} \mathrm{SO}_{4}\right]$ at the outflow of IfT-LFT in limonene ozonolysis experiment at $\mathrm{RH}=10 \%$ and $\mathrm{RH}=50 \%$. Lines show multivariate least-squares fittings according to Eq. (3).

$\mathrm{O}_{3}+$ alkene $\rightarrow \mathrm{y}_{1} \cdot \mathrm{OH}+\mathrm{y}_{2} \cdot \mathrm{sCI}+$ others

$\mathrm{sCI}+\mathrm{H}_{2} \mathrm{O} \rightarrow$ products; $k\left(\mathrm{sCI}+\mathrm{H}_{2} \mathrm{O}\right)$

$\mathrm{sCI}+\mathrm{SO}_{2} \rightarrow \ldots \rightarrow \mathrm{y}_{3} \cdot \mathrm{H}_{2} \mathrm{SO}_{4} ; k\left(\mathrm{sCI}+\mathrm{SO}_{2}\right)$

$\mathrm{sCI} \rightarrow \mathrm{OH}+$ others; $k(\mathrm{dec}$.

$\mathrm{sCI}+$ org.acid $\rightarrow$ products; $k(\mathrm{sCI}+$ acid $)$

First, ozone, when reacting with alkene, produces Criegee intermediate, which can either rapidly (picoseconds) decompose and produce $\mathrm{OH}$ (with a yield $\mathrm{y}_{1}$ ) and other products or be stabilized by collisions with the pressure gas resulting in formation of sCI with a yield $\mathrm{y}_{2}$ (Reaction R2). The sCI

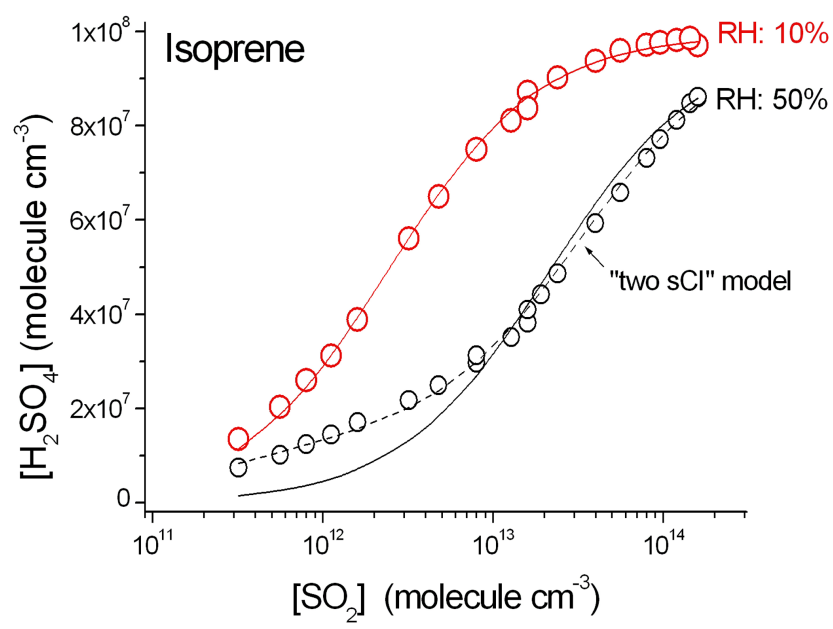

Figure 3. Loss-corrected measured $\left[\mathrm{H}_{2} \mathrm{SO}_{4}\right]$ at the outflow of IfTLFT in $\alpha$-pinene experiments at $\mathrm{RH}=10 \%$ and $\mathrm{RH}=50 \%$. Solid lines show multivariate least-squares fittings according to Eq. (3). Dashed line shows the multivariate least-squares fittings according to Eq. (5), which accounts for the different behaviour of different sCIs.

can react with water vapour (Reaction $\mathrm{R} 3$ ) or with $\mathrm{SO}_{2}(\mathrm{Re}-$ action R4). Here we assume that the $\mathrm{H}_{2} \mathrm{SO}_{4}$ formation yield $\mathrm{y}_{3}$ ) for reaction (Reaction R4) is unity (see discussion on the validity of assumption below). The sCI can also thermally decompose before reacting with other molecules, resulting in the production of $\mathrm{OH}$ and other products (Reaction R5). In addition to the unimolecular decomposition and reactions with $\mathrm{H}_{2} \mathrm{O}$ and $\mathrm{SO}_{2}$, sCI can, as we will demonstrate, react with organic acids (Reaction R6) and potentially with several other atmospheric constituents.

Since $\mathrm{OH}$ formed in reaction (R5) is efficiently scavenged (>96.9\%, at highest $\left[\mathrm{SO}_{2}\right]$; see Table 1 for propane concentrations used for different ranges of $\mathrm{SO}_{2}$ ), the reaction of remaining $(<3.1 \%) \mathrm{OH}$ with $\mathrm{SO}_{2}$ can be neglected. Even at highest $\left[\mathrm{SO}_{2}\right]$ of $2.4 \times 10^{14}$ molecules $\mathrm{cm}^{-3}$, reaction of $\mathrm{OH}$ radicals with $\mathrm{SO}_{2}$ contributes to less than $10 \%$ of total $\left[\mathrm{H}_{2} \mathrm{SO}_{4}\right]$. At $\left[\mathrm{SO}_{2}\right]$ below $1 \times 10^{14}$ molecules $\mathrm{cm}^{-3}$, the $\mathrm{OH}$ reaction can be totally neglected.

Another reaction that could be speculated to produce additional $\mathrm{H}_{2} \mathrm{SO}_{4}$ in our system is the reaction of peroxy radicals, $\mathrm{RO}_{2}$, with $\mathrm{SO}_{2}$. However, there are no clear experimental indications in the literature suggesting a fast-enough reaction of $\mathrm{RO}_{2}+\mathrm{SO}_{2}$. For example for the $\mathrm{CH}_{3} \mathrm{O}_{2}+\mathrm{SO}_{2}$ reaction, the rate coefficient is below $5 \times 10^{-17} \mathrm{~cm}^{3}$ molecule $\mathrm{s}^{-1} \mathrm{~s}^{-1}$ (DeMore et al., 1997). Theoretical findings also suggest a slow reaction (Kurtén et al., 2011). Our $\mathrm{RO}_{2}$ concentrations are of the same order or lower than atmospheric $\left[\mathrm{RO}_{2}\right]\left(\left[\mathrm{RO}_{2}\right]\right.$ cannot exceed alkene conversion), and therefore the slow reaction of $\mathrm{RO}_{2}+\mathrm{SO}_{2}$ can be disregarded in our study. Moreover, if $\mathrm{RO}_{2}+\mathrm{SO}_{2}$ were a significant source of $\left[\mathrm{H}_{2} \mathrm{SO}_{4}\right]$ in atmospheric $\mathrm{OH}$ measurements relying on 
$\mathrm{SO}_{2}$ titration (Petäjä et al., 2009, and references therein), these measurements would be wrong.

Also carbonyls or acids formed as products in the ozonolysis reaction or in the reaction of $\mathrm{OH}$ with propane could affect the results via the reaction of $\mathrm{sCI}+$ carbonyl/acid in competition with $\mathrm{sCI}+\mathrm{SO}_{2}$. Carbonyl concentration from alkene ozonolysis cannot exceed the reacted alkene concentration (should be clearly lower). Total $\mathrm{OH}$ produced upon ozonolysis cannot exceed reacted alkene concentration, and thus also carbonyls resulting from $\mathrm{OH}+$ propane cannot exceed reacted alkene concentration. Thus, maximum carbonyl concentrations in our experiment are in the range of a few $10^{8}$ molecules $\mathrm{cm}^{-3}$, i.e. 3-6 orders of magnitude lower than the $\mathrm{SO}_{2}$ concentrations used. The relative reactivity, $k\left(\mathrm{sCI}+\right.$ carbonyl) $/ k\left(\mathrm{sCI}+\mathrm{SO}_{2}\right)$, is clearly below 1 (Taatjes et al., 2012). Therefore, a potential role of the reaction $\mathrm{sCI}+$ carbonyl in our experimental system can be completely ruled out. The same applies to the reaction of organic acids with sCI. Acid formation yields are about $5 \%$ of reacted alkene, and thus the acid concentrations are in the range of $10^{7}$ molecules $\mathrm{cm}^{-3}$ (4-7 orders of magnitude lower than the $\mathrm{SO}_{2}$ concentrations). The relative reactivity, $k(\mathrm{sCI}+\mathrm{acid}) / k\left(\mathrm{sCI}+\mathrm{SO}_{2}\right)$, is $\sim 3$ as shown later in this work and qualitatively in line with Welz et al. (2014). Thus, $\mathrm{sCI}+$ acid cannot be competitive with $\mathrm{sCI}+\mathrm{SO}_{2}$ in this experiment.

Furthermore, the sCI wall loss could be important for the sCI balance. The first-order rate coefficient for the diffusion-limited wall loss of sCI can be estimated according to $k_{\text {wall-loss }}=3.65 \cdot D / r^{2}$, where $D$ is the diffusion coefficient of $\mathrm{sCI}$ and $r$ stands for the tube radius. As the diffusion coefficient a value of $0.1 \mathrm{~cm}^{2} \mathrm{~s}^{-1}$ was assumed $\left(D\left(\mathrm{H}_{2} \mathrm{SO}_{4}\right)=0.08 \mathrm{~cm}^{2} \mathrm{~s}^{-1}\right)$, resulting in $k_{\mathrm{wall}}$ loss $=0.023 \mathrm{~s}^{-1}$. Thermal decomposition of sCI is expected to be much more rapid (Welz et al., 2012; Berndt et al., 2012), making the sCI wall loss negligible in the kinetic analysis.

In the absence of organic acid added to the reaction gas, only Reactions (R2)-(R5) are considered. The fraction of $\mathrm{SCI}$ that oxidizes $\mathrm{SO}_{2}$, producing sulfuric acid $\left(\mathrm{sCI}_{\mathrm{H}_{2} \mathrm{SO}_{4}} / \mathrm{sCI}_{\mathrm{TOT}}\right)$, is equal to the sCI reaction rate with $\mathrm{SO}_{2}$ (Reaction $\mathrm{R} 4$ ) divided by the sum of all reaction rates (total reaction rate) of sCI (Reactions R3-R5):

$$
\frac{\mathrm{sCl}_{\mathrm{H}_{2} \mathrm{SO}_{4}}}{\mathrm{sCI}_{\mathrm{TOT}}}=\frac{k\left(\mathrm{sCI}+\mathrm{SO}_{2}\right)\left[\mathrm{SO}_{2}\right]}{k\left(\mathrm{sCI}+\mathrm{SO}_{2}\right)\left[\mathrm{SO}_{2}\right]+k(\mathrm{dec})+k\left(\mathrm{sCI}+\mathrm{H}_{2} \mathrm{O}\right)\left[\mathrm{H}_{2} \mathrm{O}\right]} .
$$

It follows for a given $\mathrm{RH}$ and $k($ loss $)=k(\mathrm{dec})+k\left(\mathrm{sCI}+\mathrm{H}_{2} \mathrm{O}\right) \cdot\left[\mathrm{H}_{2} \mathrm{O}\right]$ that the total concentration of sulfuric acid produced during the experiment is

$\left[\mathrm{H}_{2} \mathrm{SO}_{4}\right]=\frac{1}{1+\frac{k(\text { loss })}{k\left(\mathrm{SCI}+\mathrm{SO}_{2}\right)\left[\mathrm{SO}_{2}\right]}} \cdot\left[\mathrm{H}_{2} \mathrm{SO}_{4}\right]_{\mathrm{SCI}}$,

where $\left[\mathrm{H}_{2} \mathrm{SO}_{4}\right]_{\mathrm{sCI}}$ stands for $\left[\mathrm{H}_{2} \mathrm{SO}_{4}\right]$ from sCI titration; i.e all $\mathrm{sCI}$ is converted to $\mathrm{H}_{2} \mathrm{SO}_{4}$ in the presence of high $\mathrm{SO}_{2}$ concentrations via Reaction (R4), making Reactions (R3) and (R5) negligible. In the analysis we assumed $28 \%$ wall loss in total sulfuric acid concentration (Berndt et al., 2014a), and the measured values were corrected for the wall loss before being used in the data analysis.

The yield $\mathrm{y}_{2}$ of sCI from Reaction (R2) can be obtained from the knowledge of the reacted alkene and $\left[\mathrm{H}_{2} \mathrm{SO}_{4}\right]_{\mathrm{SCI}}$ assuming a $\mathrm{H}_{2} \mathrm{SO}_{4}$ yield of unity from Reaction (R4):

$y_{2}=\frac{\left[\mathrm{H}_{2} \mathrm{SO}_{4}\right]_{\mathrm{sCl}}}{\text { reacted [alkene }]}$.

The amount of reacted alkene and ozone was kept very small (less than $1 \%$ each), allowing us to calculate the reacted alkene concentration according to Eq. (5) (see also Table 1):

reacted[alkene $]=k\left(\mathrm{O}_{3}+\right.$ alkene $) \cdot[$ alkene $] \cdot\left[\mathrm{O}_{3}\right] \cdot t$.

The relative rate coefficients $k(\mathrm{loss}) / k\left(\mathrm{sCI}+\mathrm{SO}_{2}\right)$ and the $\mathrm{sCI}$ yield $\mathrm{y}_{2}$ were obtained by least-squares fitting according to Eqs. (3) and (4), using the experimental data depicted in Figs. 1-3.

The above approach assumes that all sCIs formed from a selected alkene show a similar reactivity in Reaction (R3)-(R5), i.e. that we are able to describe only average effects of all sCIs. Ozonolysis of a single alkene can result in the production of different types of CI and thus sCI. In the case of $\alpha$-pinene, possible sCIs include two different isomers, one syn- and one which can be either a syn- or anticonformer, with syn having two different structures possible; all in all sCI from $\alpha$-pinene ozonolysis can have four different structures. The same applies for limonene. Nevertheless, the "one-sCI" approach seems to work well for $\alpha$ pinene and limonene, suggesting that one of the possible sCI structures dominates, or that different sCIs show similar $k($ loss $) / k\left(\mathrm{sCI}+\mathrm{SO}_{2}\right)$. With the help of the single-sCI model, Eq. (3), the experimental data are described reasonably well (Figs. 1 and 2). For isoprene, due to the structure of the parent alkene, five different sCI structures are possible. In this case the one-sCI model is too simple for a reliable description of the measurements; see below.

For monoterpenes, increasing the water vapour concentration by a factor of 5 did not change the results within the experimental uncertainties. This indicates that thermal decomposition dominates the loss mechanism of sCI under these conditions and the reaction with water vapour is of less importance; i.e. $k(\mathrm{dec}$. $) \gg k\left(\mathrm{sCI}+\mathrm{H}_{2} \mathrm{O}\right) \cdot\left[\mathrm{H}_{2} \mathrm{O}\right]$ for $\left[\mathrm{H}_{2} \mathrm{O}\right] \leq 2.9 \times 10^{17}$ molecules $\mathrm{cm}^{-3}$. The relative rate coefficients and yields from monoterpene ozonolysis experiments are summarized in Table 2.

The experiments with isoprene showed a different behaviour. At low water vapour concentration, $\mathrm{RH}=10 \%$, the above approach of the one-sCI model fits well to the experimental data. At an elevated water vapour concentration $(\mathrm{RH}=50 \%)$, a significant drop in sulfuric acid concentration is observed and the one-sCI model fails in describing 
Table 2. Results according to Eqs. (3) and (4) from non-linear regression analysis $\left[\mathrm{H}_{2} \mathrm{SO}_{4}\right]=\mathrm{f}\left(\left[\mathrm{SO}_{2}\right]\right)$.

\begin{tabular}{llll}
\hline Alkene & $k($ loss $) / k\left(\mathrm{sCI}+\mathrm{SO}_{2}\right)$ molecules cm & & {$\left[\mathrm{H}_{2} \mathrm{SO}_{4}\right]_{\mathrm{sCI}}$ molecules cm } \\
\hline$\alpha$-Pinene & $(2.4 \pm 0.2) \times 10^{12} \mathrm{RH}: 10 \%$ & $(1.15 \pm 0.02) \times 10^{8} \mathrm{RH}: 10 \%$ & \multirow{2}{*}{ sCI yield } \\
& $(2.0 \pm 0.4) \times 10^{12} \mathrm{RH}: 50 \%$ & $(1.13 \pm 0.04) \times 10^{8} \mathrm{RH}: 50 \%$ & \\
\hline Limonene & $(2.4 \pm 0.2) \times 10^{12} \mathrm{RH}: 10 \%$ & $(9.3 \pm 0.1) \times 10^{7} \mathrm{RH}: 10 \%$ & 0.07 \\
& $(2.1 \pm 0.2) \times 10^{12} \mathrm{RH}: 50 \%$ & $(9.3 \pm 0.2) \times 10^{7} \mathrm{RH}: 50 \%$ & \\
\hline Isoprene & $(2.5 \pm 0.1) \times 10^{12} \mathrm{RH}: 10 \%$ & $(9.9 \pm 0.1) \times 10^{7} \mathrm{RH}: 10 \%$ & $0.58 \pm 0.26$ \\
& $(2.1 \pm 0.5) \times 10^{13} \mathrm{RH}: 50 \% *$ & $(9.7 \pm 0.6) \times 10^{7} \mathrm{RH}: 50 \%$ & \\
\hline
\end{tabular}

* for a "two-sCl" model we get $3.3 \times 10^{13}$ and $2.6 \times 10^{11}$ assuming the same total $\left[\mathrm{H}_{2} \mathrm{SO}_{4}\right]_{\mathrm{SCI}}$, where the first sCI accounts for $\sim 85 \%$ and the second for $\sim 15 \%$.

the measurements. The flaw of the one-sCI model can be explained by the different reactivity of different sCIs toward water vapour. To account for the possible differences in the reactivity of different sCIs, Eq. (3) was extended to a "twosCI model" considering a different reactivity of $\mathrm{sCI}_{\mathrm{I}}$ and $\mathrm{sCI}_{\mathrm{II}}$ in Reactions (R3)-(R5):

$$
\begin{aligned}
& {\left[\mathrm{H}_{2} \mathrm{SO}_{4}\right]=\frac{1}{1+\frac{k(\mathrm{loss})_{I}}{k\left(\mathrm{sCI}+\mathrm{SO}_{2}\right)_{I}\left[\mathrm{SO}_{2}\right]}} \cdot\left[\mathrm{H}_{2} \mathrm{SO}_{4}\right]_{\mathrm{SCI}_{\mathrm{I}}}} \\
& +\frac{1}{1+\frac{k\left(\mathrm{loss}_{\mathrm{II}}\right.}{k\left(\mathrm{sCI}+\mathrm{SO}_{2}\right)_{\mathrm{II}}\left[\mathrm{SO}_{2}\right]}} \cdot\left[\mathrm{H}_{2} \mathrm{SO}_{4}\right]_{\mathrm{SCI}_{\mathrm{II}}}
\end{aligned}
$$

Non-linear regression analysis to the experimental data suggests that the "first sCI" (type I) is responsible on $85 \%$ and the "second sCI" (type II) on $15 \%$ of the total measured $\left[\mathrm{H}_{2} \mathrm{SO}_{4}\right]_{\mathrm{SCI}}$. Furthermore, it shows that the relative rates coefficients $k$ (loss) $/ k\left(\mathrm{sCI}+\mathrm{SO}_{2}\right)$ are significantly different between the two sCIs: $3.3 \times 10^{13}$ molecules $\mathrm{cm}^{-3}$ for type I and $2.6 \times 10^{11}$ molecules $\mathrm{cm}^{-3}$ for type II. From our experiment we cannot draw clear conclusions on what kind of sCI formed from the isoprene ozonolysis is responsible for type I and type II. It could be speculated that $\mathrm{CH}_{2} \mathrm{OO}$ and/or an anti-conformer sCI causes the strong $\mathrm{RH}$ dependence of produced sulfuric acid due to their efficient reaction with water vapour (Reaction R3) in competition with Reaction (R4). The relative rate coefficients and yields are summarized in Table 2 .

If the fast reaction with water is due to $\mathrm{CH}_{2} \mathrm{OO}$, that might have implications for our understanding of CI chemistry and the inclusion of the results by Welz et al. (2012) in models, including global chemical transport models (Pierce et al., 2013). Stone et al. (2014) suggest a relatively slow water reaction obtained by a technique similar to the approach by Welz et al. (2012), while the older measurements suggest that the water reaction dominates in the atmosphere over "all" other reactions; see for example Hasson et al. (2001a). Recent work by Berndt et al. (2014b) also suggests that reaction with water (dimer) is relatively fast dominating the atmospheric fate of $\mathrm{CH}_{2} \mathrm{OO}$. The relative rate coefficients $k$ (loss) $/ k\left(\mathrm{sCI}+\mathrm{SO}_{2}\right)$ obtained in this study are close to those obtained by Berndt et al. (2012) for sCI from the ozonolysis of trans-2-butene and TME. Berndt et al. (2014a) also showed that significant differences in the relative rate coefficients $k\left(\mathrm{sCI}+\mathrm{H}_{2} \mathrm{O}\right) / k\left(\mathrm{sCI}+\mathrm{SO}_{2}\right)$ occurred between syn- and anti-confomers of sCI from trans-2-butene. Absolute measurements by Taatjes et al. (2012) support this finding as well.

Similar to Berndt et al. (2012, 2014a, b), our analysis of the relative rate coefficients and $\mathrm{sCI}$ yields incorporates the yield of $\mathrm{H}_{2} \mathrm{SO}_{4}$ from the $\mathrm{SCI}+\mathrm{SO}_{2}$ reaction - i.e. our investigation is limited to the channel leading to the formation of $\mathrm{H}_{2} \mathrm{SO}_{4}$. However, the yields cannot be significantly below unity, since otherwise the obtained yields of sCI should be higher by the same factor. As the sCI yield cannot exceed unity, we conclude that the yield of $\mathrm{H}_{2} \mathrm{SO}_{4}$ from the $\mathrm{sCI}+\mathrm{SO}_{2}$ reaction must be, if not unity, at least $>0.2$ for monoterpene sCIs and $>0.5$ for isoprene sCIs. However, there is reason to believe that the $\mathrm{H}_{2} \mathrm{SO}_{4}$ yields are much higher than that and thus very close to unity; our measured sCI yield for $\alpha$-pinene of $0.15 \pm 0.07$ assuming a unity $\mathrm{H}_{2} \mathrm{SO}_{4}$ yield from $\mathrm{sCI}+\mathrm{SO}_{2}$ is in excellent agreement with a yield of 0.15 recently determined with an sCI-specific scavenger technique (Drozd and Donahue, 2011). These observations also call into question the stable, non- $\mathrm{SO}_{3}$-producing, sulfur-bearing secondary ozonides, theoretically investigated by Kurtén et al. (2011) and Vereecken et al. (2012), as a predominant product from the $\mathrm{sCI}+\mathrm{SO}_{2}$ reaction.

Our results on the relative rate coefficient can be compared to those calculated from the data reported by Welz et al. (2012), who, as discussed above, studied the simplest possible Criegee $\left(\mathrm{CH}_{2} \mathrm{OO}\right)$ in a low-pressure system. They found $\quad k\left(\mathrm{sCI}+\mathrm{SO}_{2}\right)=3.9 \times 10^{-11} \mathrm{~cm}^{3}$ molecule ${ }^{-1} \mathrm{~s}^{-1}$ to be the lower-end estimation for the lifetime against decomposition of $2 \mathrm{~ms}$ - resulting in upper-end estimation for $k(\mathrm{dec})$ of $500 \mathrm{~s}^{-1}-$ and the upperend estimation for reaction coefficient with $\mathrm{H}_{2} \mathrm{O}$ of $k\left(\mathrm{sCI}+\mathrm{H}_{2} \mathrm{O}\right)<4 \times 10^{-15} \mathrm{~cm}^{3}$ molecule $\mathrm{s}^{-1} \mathrm{~s}^{-1}$. Using the upper-end rate coefficients for $\mathrm{CH}_{2} \mathrm{OO}$ in $k($ loss $)=k(\mathrm{dec})+k\left(\mathrm{sCI}+\mathrm{H}_{2} \mathrm{O}\right) \cdot\left[\mathrm{H}_{2} \mathrm{O}\right]$, for the relative reaction rate coefficients $k($ loss $) / k\left(\mathrm{sCI}+\mathrm{SO}_{2}\right)$ follow $<1.9 \times 10^{13}$ molecules $\mathrm{cm}^{-3} \quad(\mathrm{RH}=10 \%)$ and 


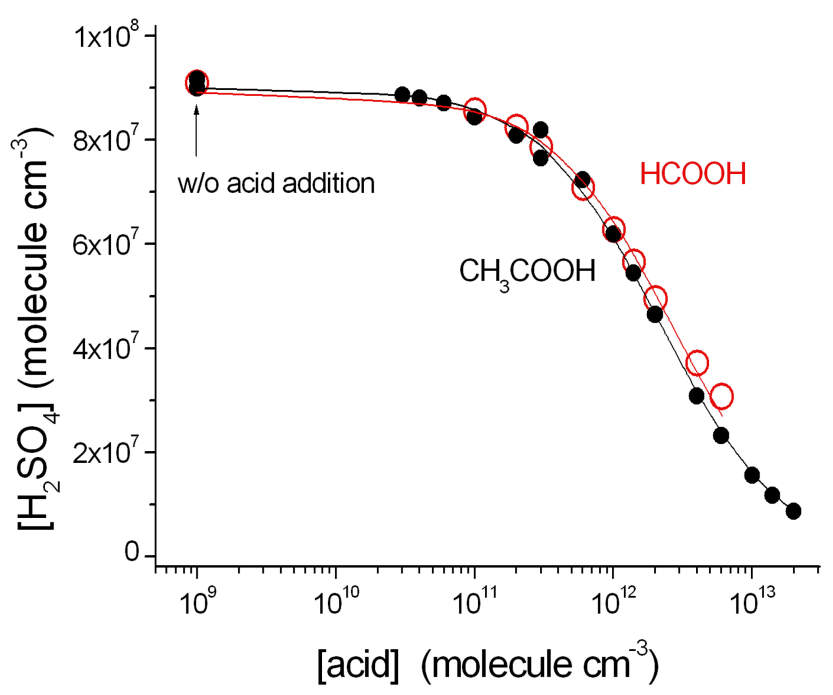

Figure 4. Experimental data from the competitive reaction kinetics experiments, $\mathrm{sCI}+\mathrm{SO}_{2}$ vs. $\mathrm{sCI}+$ acid, $\mathrm{sCI} \equiv\left(\mathrm{CH}_{3}\right)_{2} \mathrm{COO}$ (from TME ozonolysis). The lines show the best-fit result of the non-linear regression analysis from Eq. (7).

$<4.2 \times 10^{13}$ molecules $\mathrm{cm}^{-3} \quad(\mathrm{RH}=50 \%)$, being qualitatively not in contradiction with our results for the sCIs of the monoterpenes and isoprene; see Table 2. If the reaction of $\mathrm{CH}_{2} \mathrm{OO}$ with $\mathrm{H}_{2} \mathrm{O}$ dominated the loss process $\left(k(\mathrm{dec}) \ll k\left(\mathrm{sCI}+\mathrm{H}_{2} \mathrm{O}\right) \cdot\left[\mathrm{H}_{2} \mathrm{O}\right]\right)$, the resulting $k$ (loss) $/ k\left(\mathrm{sCI}+\mathrm{SO}_{2}\right)$ ratios from Welz et al. (2012) data would be $<5.9 \times 10^{12}$ molecules $\mathrm{cm}^{-3} \quad(\mathrm{RH}=10 \%)$ and $<3.0 \times 10^{13}$ molecules $\mathrm{cm}^{-3} \quad(\mathrm{RH}=50 \%)$, still not contradicting our findings. A more detailed comparison is impossible because the study by Welz et al. (2012) yielded only upper limits for the rate coefficients of the sCI decomposition step (R5) and the reaction of sCI with $\mathrm{H}_{2} \mathrm{O}$ (Reaction R3). Since pressures in our work and the study by Welz et al. (2012) were completely different, differences related to pressure effects may arise. It is to be noted also here that Reactions (R3) and/or (R5) describe the most important atmospheric loss processes. For a reliable assessment of the importance of $\mathrm{H}_{2} \mathrm{SO}_{4}$ formation in the atmosphere via $\mathrm{sCI}+\mathrm{SO}_{2}$, the sCI main reactions (Reactions $\mathrm{R} 3$ and $\mathrm{R} 5$ ) must be characterized very well.

\subsection{Reaction of sCI with organic acids}

The reaction of acetone oxide $\left(\left(\mathrm{CH}_{3}\right)_{2} \mathrm{COO}\right.$, sCI from TME ozonolysis) with small organic acids was investigated by a competitive reaction kinetics experiment at constant $\mathrm{SO}_{2}$ concentration $\left(3.2 \times 10^{12}\right.$ molecules $\left.\mathrm{cm}^{-3}\right)$ and varying the concentration of the organic acids (Fig. 4).

Berndt et al. (2014a) showed that for acetone oxide the reaction with water vapour (Reaction R3) is of less importance compared with the thermal decomposition (Reaction R5) for $\mathrm{RH} \leq 50 \%$. Our experiment was conducted at
Table 3. Relative reaction rate coefficients for reaction of $\left(\mathrm{CH}_{3}\right)_{2} \mathrm{COO}$ (sCI from TME ozonolysis) with small organic acids and $\mathrm{SO}_{2}$ based on competitive reaction kinetics experiments.

\begin{tabular}{lll}
\hline Acid & $\begin{array}{l}k(\mathrm{sCI}+\text { acid }) / \\
k\left(\mathrm{sCI}+\mathrm{SO}_{2}\right)\end{array}$ & $\begin{array}{l}{\left[\mathrm{H}_{2} \mathrm{SO}_{4}\right]_{\mathrm{sCI}},} \\
\text { molecules cm }\end{array}$ \\
\hline $\mathrm{HCOOH}$, formic acid & $(2.80 \pm 0.32)$ & $2.05 \times 10^{8}$ \\
$\mathrm{CH}_{3} \mathrm{COOH}$, acetic acid & $(3.43 \pm 0.22)$ & $2.05 \times 10^{8}$ \\
\hline
\end{tabular}

low RH (10\%), and thus only the thermal decomposition of sCI was considered together with the reactions of sCI with $\mathrm{SO}_{2}$ (Reaction R4) and the acids (Reaction R6). From pathways (R4)-(R6) follows

$\left[\mathrm{H}_{2} \mathrm{SO}_{4}\right]=\frac{1}{1+\frac{k(\mathrm{dec})}{k\left(\mathrm{SCI}+\mathrm{SO}_{2}\right)\left[\mathrm{SO}_{2}\right]}+\frac{k(\mathrm{sCl}+\mathrm{acid})[\mathrm{acid}]}{k\left(\mathrm{SCI}+\mathrm{SO}_{2}\right)\left[\mathrm{SO}_{2}\right]}} \cdot\left[\mathrm{H}_{2} \mathrm{SO}_{4}\right]_{\mathrm{SCI}} \cdot$

The relative rate coefficient $k(\mathrm{dec}) / k\left(\mathrm{sCI}+\mathrm{SO}_{2}\right)$ was determined by Berndt et al. (2014a) to be $4.2 \times 10^{12}$ molecules $\mathrm{cm}^{-3}$. $\left[\mathrm{H}_{2} \mathrm{SO}_{4}\right]$ stands again for the loss-corrected sulfuric acid concentration at the IfTLFT outflow and $\left[\mathrm{H}_{2} \mathrm{SO}_{4}\right]_{\mathrm{sCI}}$ for $\left[\mathrm{H}_{2} \mathrm{SO}_{4}\right]$ from sCI titration. Results from the non-linear regression analysis $\left[\mathrm{H}_{2} \mathrm{SO}_{4}\right]=f([\mathrm{acid}])$ from Eq. (7) yield the free parameters $k(\mathrm{sCI}+\mathrm{acid}) / k\left(\mathrm{sCI}+\mathrm{SO}_{2}\right)$ and $\left[\mathrm{H}_{2} \mathrm{SO}_{4}\right]_{\mathrm{sCI}}$; see Table 3 . Our measurements reveal an about-3-times-faster reaction of acetone oxide with the acids compared with the reaction with $\mathrm{SO}_{2}$.

Neeb et al. (1997) measured rapid reaction of $\mathrm{sCI}+\mathrm{HCOOH}$ in comparison to $\mathrm{sCI}+$ water. However, our results cannot be directly compared to Neeb et al. (1997) due to different water reactivity of $\mathrm{CH}_{2} \mathrm{OO}$ (studied by Neeb et al., 1997) and $\left(\mathrm{CH}_{3}\right)_{2} \mathrm{COO}$ investigated here (Berndt et al., 2014b). However, our result is very similar to the reaction rate coefficients reported by Welz et al. $(2012 ; 2104)$ for reactions of $\mathrm{CH}_{2} \mathrm{OO}$ with $\mathrm{SO}_{2}$ and $\mathrm{HCOOH} / \mathrm{CH}_{3} \mathrm{COOH}$. Welz et al. $(2012 ; 2014)$ studies demonstrate the relative reactivity of 2.8 and 3.3 for $k(\mathrm{sCI}+\mathrm{HCOOH}) / k\left(\mathrm{sCI}+\mathrm{SO}_{2}\right)$ and for $k\left(\mathrm{sCI}+\mathrm{CH}_{3} \mathrm{COOH}\right) / k\left(\mathrm{sCI}+\mathrm{SO}_{2}\right)$, respectively. These values are stunningly close to our measured values of 2.8 and 3.4, though it should be kept in mind that our sCI represents $\left(\mathrm{CH}_{3}\right)_{2} \mathrm{COO}$ while Welz et al. $(2012,2014)$ data are for $\mathrm{CH}_{2} \mathrm{OO}$.

Now we discuss the potential importance of the sCI + acid reaction in the atmosphere. Mauldin III et al. (2012) estimated the absolute reaction rate coefficient of $\mathrm{sCI}+\mathrm{SO}_{2}$ to be in the range of $6 \times 10^{-13} \mathrm{~cm}^{3}$ molecule ${ }^{-1} \mathrm{~s}^{-1}$ for $\alpha$-pinene and limonene. Using this value, the absolute reaction rate coefficient for $\mathrm{sCI}+\mathrm{HCOOH}$ and sCI $+\mathrm{CH}_{3} \mathrm{COOH}$ would be in the range of a few $10^{-12} \mathrm{~cm}^{3}$ molecule $\mathrm{e}^{-1} \mathrm{~s}^{-1}$. The reaction rate coefficient for $\mathrm{OH}+\mathrm{CH}_{3} \mathrm{COOH}$ is $8 \times 10^{-13} \mathrm{~cm}^{3}$ molecule $\mathrm{e}^{-1} \mathrm{~s}^{-1}$ and for $\mathrm{OH}+\mathrm{HCOOH} 4 \times 10^{-13} \mathrm{~cm}^{3}$ molecule $\mathrm{e}^{-1}$. As shown by Mauldin III et al. (2012), the summertime sCI concentra- 
tions are similar to $\mathrm{OH}$ peak concentrations in boreal forest. Therefore, it is possible that sCI oxidation plays a crucial role for the $\mathrm{HCOOH}$ and $\mathrm{CH}_{3} \mathrm{COOH}$ budget. However, as stated above, the conformation and structure of sCI probably have major effects on the sCI reactivity toward acids, and therefore further investigations are required before our observations can be generalized to sCIs other than acetone oxide. On the other hand, Welz et al. (2014) measured for $\mathrm{CH}_{2} \mathrm{OO}+\mathrm{HCOOH} / \mathrm{CH}_{3} \mathrm{COOH}$ rate coefficients exceeding $10^{-10} \mathrm{~cm}^{3}$ molecule ${ }^{-1} \mathrm{~s}^{-1}$, suggesting that this structurally different sCI $\left(\mathrm{CH}_{2} \mathrm{OO}\right)$ also reacts with acids rapidly in comparison to the $\mathrm{OH}$ radical reaction.

It is important to notice that, even though from sCI point of view $\mathrm{SO}_{2}$ or organic acids were the minor sinks for sCI, the situation can be completely opposite from the point of view of formation of $\mathrm{H}_{2} \mathrm{SO}_{4}$ (Boy et al., 2013; Pierce et al., 2013) or the loss of organic acids (Welz et al., 2014). Most likely, the dominating reactions controlling the $\mathrm{sCI}$ concentrations in natural environments are thermal decomposition and reaction with water vapour. Very high concentrations (several to tens of $\mathrm{ppb}$ ) of $\mathrm{SO}_{2}$ or organic acids would be required to alter the sCI budget significantly. However, the reaction with $\mathrm{sCI}$ can still be a significant or even the main fate of acid or source of $\mathrm{H}_{2} \mathrm{SO}_{4}$.

Regarding the role of sCI in atmospheric gas phase $\mathrm{H}_{2} \mathrm{SO}_{4}$ production, the present study is in a reasonable agreement with the results by Mauldin III et al. (2012). Therefore results by Boy et al. (2013), who applied Mauldin III et al. (2012) findings in boundary layer modelling, can be considered valid as well. Pierce et al. (2013) applied Welz et al. (2012) results in a chemical transport model for studying the role of sCI in global gas phase $\mathrm{H}_{2} \mathrm{SO}_{4}$ burden. Because our relative rate coefficient between $\mathrm{sCI}$ loss and $\mathrm{sCI}+\mathrm{SO}_{2}$ are not conflicting with the results by Welz et al. (2012), our present results validate, form one side, also the modelling study by Pierce et al. (2013). Thus, our understanding of the role of sCI in atmospheric $\mathrm{H}_{2} \mathrm{SO}_{4}$ production remains unchanged.

\section{Conclusions and summary}

We investigated experimentally the sCI yield and relative rate coefficient $k($ loss $) / k\left(\mathrm{sCI}+\mathrm{SO}_{2}\right)$ for the sCI loss reaction, $k($ loss $)=k(\mathrm{dec})+.k\left(\mathrm{sCI}+\mathrm{H}_{2} \mathrm{O}\right) \cdot\left[\mathrm{H}_{2} \mathrm{O}\right]$, and the $\mathrm{H}_{2} \mathrm{SO}_{4}$-producing reaction of sCI with $\mathrm{SO}_{2}$. The values $k$ (loss) $/ k\left(\mathrm{sCI}+\mathrm{SO}_{2}\right)$ are the key quantities for an assessment of the role of $\mathrm{sCI}$ for the sulfuric acid production in the atmosphere via $\mathrm{SCI}+\mathrm{SO}_{2}$. Investigations probed $\mathrm{sCI}$ from the ozonolysis of isoprene and two monoterpenes, $\alpha$ pinene and limonene, at ambient-relevant temperature, pressure and humidity. The observed quantities represent average values of all sCIs produced from the individual alkene. The sCI yields were in the range of a few tens of percent and similar to the yields determined for smaller sCIs using the same approach (Berndt et al., 2014a) or an- other sCI-specific scavenger technique (Drozd and Donahue, 2011). For the studied monoterpenes, the relative rate coefficients $k($ loss $) / k\left(\mathrm{sCI}+\mathrm{SO}_{2}\right)$ were in the range of (2.0-2.4) $\times 10^{12}$ molecules $\mathrm{cm}^{-3}$, with no measurable effect on the relative humidity ( $\mathrm{RH}=10$ or $50 \%$ ). In the case of the isoprene-derived sCIs, an efficient reaction with water vapour was observed making $k(\operatorname{loss}) / k\left(\mathrm{sCI}+\mathrm{SO}_{2}\right)$ strongly $\mathrm{RH}$-dependent. We also showed that, beyond the contribution to sulfuric acid formation, sCI can react rapidly with small organic acids, and thus potentially with several other atmospheric constituents, suggesting that sCIs have a more general role in the atmospheric oxidation chemistry than $\mathrm{SO}_{2}$ oxidation alone. Further investigations are necessary for obtaining a holistic and detailed understanding of the sCI chemistry and the role of $\mathrm{sCI}$ in the formation and loss of various atmospheric species.

Acknowledgements. Support of the Academy of Finland (251427, 139656, Finnish Centre of Excellence 141135), the PEGASOS project funded by the European Commission under the Framework Programme 7 (FP7-ENV-2010-265148), the European Research Council (ATMNUCLE) and NASA/ROSES is acknowledged. We thank Ari Asmi for useful discussions and K. Pielok and A. Rohmer for technical assistance

Edited by: F. Keutsch

\section{References}

Atkinson, R.: Atmospheric chemistry of VOCs and $\mathrm{NO}_{\mathrm{x}}$, Atmosph. Env., 34, 2063-2101, 2000.

Berndt, T., Böge, O., Stratmann, F., Heintzenberg, J., and Kulmala, M.: Rapid Formation of Sulfuric Acid Particles at NearAtmospheric Conditions, Science, 307, 698-700, 2005.

Berndt, T., Jokinen, T., Mauldin III, R. L., Petäjä, T., Herrmann, H., Junninen, H., Paasonen, P., Worsnop, D. R., and Sipilä, M.: GasPhase Ozonolysis of Selected Olefins: The Yield of Stabilized Criegee Intermediate and the Reactivity toward $\mathrm{SO}_{2}$, J. Phys. Chem. Lett. 3, 2892-2896, 2012.

Berndt, T., Jokinen, T., Sipilä, M, Mauldin, III, R. L., Herrmann, H., Stratmann, F., Junninen, H., and Kulmala, M.: $\mathrm{H}_{2} \mathrm{SO}_{4}$ formation from the gas-phase reaction of stabilized Criegee Intermediates with $\mathrm{SO}_{2}$ : Influence of water vapour content and temperature, Atmos. Environ., 89, 603-612, 2014a.

Berndt, T., Voigtländer, J., Stratmann, F., Junninen, H., Mauldin III, R. L., Sipilä, M., Kulmala, M., and Herrmann, H.: Competing atmospheric reactions of $\mathrm{CH}_{2} \mathrm{OO}$ with $\mathrm{SO}_{2}$ and water vapour, Phys. Chem. Chem. Phys., 16, 19130-19136, doi:10.1039/c4cp02345e, 2014b.

Boy, M., Mogensen, D., Smolander, S., Zhou, L., Nieminen, T., Paasonen, P., Plass-Dülmer, C., Sipilä, M., Petäjä, T., Mauldin, L., Berresheim, H., and Kulmala, M.: Oxidation of $\mathrm{SO}_{2}$ by stabilized Criegee intermediate ( $\mathrm{sCI}$ ) radicals as a crucial source for atmospheric sulfuric acid concentrations, Atmos. Chem. Phys., 13, 3865-3879, doi:10.5194/acp-13-3865-2013, 2013.

Calvert, J. G., Atkinson, R., Kerr, J. A., Madronich, S., Moortgat, G. K., Wallington, T. J., and Yarwood, G.: The Mechanism of 
Atmospheric Oxidation of the Alkenes, Oxford University Press, New York, USA, 552 pp., 2000.

Criegee, R., Mechanism of Ozonolysis, Angew. Chem., Int. Ed., 14, $745-752,1975$.

DeMore, W. B., Sander, S. P., Golden, D. M., Hampson, R. F., Kurylo, M. J., Howard, C. J., Ravishankara, A. R., Kolb, C. E., and Molina, M. J.: Chemical Kinetics and Photochemical Data for Use in Stratospheric Modeling, Evaluation Number 12, Jet Propulsion Laboratory (JPL) Publication 97-4, Pasadena, California, 1997.

Di Carlo, P., Brune, W. H., Martinez, M., Harder, H., Lesher, R., Ren, X., Thornberry, T., Carroll, M. A., Young, V., Shepson, P. B., Riemer, D., Apel, E., and Campbell, C.: Missing OH reactivity in a forest: Evidence for unknown reactive biogenic VOCs, Science, 304, 722-724, 2004.

Drozd, G. T. and Donahue, N. M.: Pressure Dependence of Stabilized Criegee Intermediate Formation from a Sequence of Alkenes. J. Phys. Chem. A, 115, 4381-4387, 2011.

Ehn, M., Thornton, J. A., Kleist, E., Sipilä, M., Junninen, H., Pullinen, I., Springer, M., Rubach, F., Tillmann, R., Lee, B., LopezHilfiker, F., Andres, S., Acir, I.-H., Rissanen, M., Jokinen, T., Schobesberger, S., Kangasluoma, J., Kontkanen, J., Nieminen, T., Kurtén, T., Nielsen, L. B., Jørgensen, S., Kjaergaard, H. G., Canagaratna, M., Dal Maso, M., Berndt, T., Petäjä, T., Wahner, A., Kerminen, V., Kulmala, M., Worsnop, D. R., Wildt, J, and Mentel, T. F.: A large source of low-volatility secondary organic aerosol, Nature, 506, 476-479, doi:10.1038/nature13032, 2014. Eisele, F. L. and Tanner, D. J.: Measurement of the gas phase concentration of $\mathrm{H} 2 \mathrm{SO} 4$ and methane sulfonic acid and estimates of $\mathrm{H}_{2} \mathrm{SO}_{4}$ production and loss in the atmosphere, J. Geophys. Res. 98, 9001-9010, 1993.

Fenske, J. D., Hasson, A. S., Ho, A. W., and Paulson, S. E.: Measurement of absolute unimolecular and bimolecular rate constants for $\mathrm{CH}_{3} \mathrm{CHOO}$ generated by the trans-2-butene reaction with ozone in the gas phase, J. Phys. Chem. A, 104, 9921-9932, 2000.

Hasson, A. S., Orzechowska, G., and Paulson, S. E.: Production of stabilized Criegee intermediates and peroxides in the gas phase ozonolysis of alkenes 1 . Ethene, trans-2-butene, and 2,3dimethyl-2-butene, J. Geophys. Res., 106, 34131-34142, 2001 a.

Hasson, A. S., Ho, A. W., Kuwata, K. T., and Paulson, S. E.: Production of stabilized criegee intermediates and peroxides in the gas phase ozonolysis of alkenes 2. Asymmetric and biogenic alkenes, J. Geophys. Res., 106, 34143-34153, 2001 b.

Hasson, A., Chung, M., Kuwata, K., Converse, A., Krohn, D., and Paulson, S.: Reaction of Criegee intermediates with water vapor - An additional source of $\mathrm{OH}$ radicals in alkene ozonolysis?, J. Phys. Chem. A, 107, 6176-6182, 2003.

Hofzumahaus, A., Rohrer, F. Lu, K., Bohn, B., Brauers, T., Chang, C-C., Fuchs, H., Holland, F., Kita, K., Kondo, Y., Li, X., Lou, S., Shao, M., Zeng, L., Wahner, A., and Zhang, Y. Amplified Trace Gas Removal in the Troposphere, Science, 324, 1702-1704, 2009.

Johnson, D., Lewin, A. G., and Marston, G.: The Effect of CriegeeIntermediate Scavengers on the $\mathrm{OH}$ Yield from the Reaction of Ozone with 2-Methyl-2-butene., J. Phys. Chem. A, 105, 2933-2935, 2001.

Jokinen, T., Sipilä, M., Junninen, H., Ehn, M., Lönn, G., Hakala, J., Petäjä, T., Mauldin III, R. L., Kulmala, M., and Worsnop,
D. R.: Atmospheric sulphuric acid and neutral cluster measurements using CI-APi-TOF, Atmos. Chem. Phys., 12, 4117-4125, doi:10.5194/acp-12-4117-2012, 2012.

Junninen, H., Ehn, M., Petäja, T., Luosujärvi, L., Kotiaho, T., Kostiainen, R., Rohner, U., Gonin, M., Fuhrer, K., Kulmala, M., and Worsnop, D. R.: A high-resolution mass spectrometer to measure atmospheric ion composition, Atmos. Meas. Tech., 3, 1039-1053, doi:10.5194/amt-3-1039-2010, 2010.

Kerminen, V.-M., Petäjä, T., Manninen, H. E., Paasonen, P., Nieminen, T., Sipilä, M., Junninen, H., Ehn, M., Gagné, S., Laakso, L., Riipinen, I., Vehkamäki, H., Kurtén, T., Ortega, I. K., Dal Maso, M., Brus, D., Hyvärinen, A., Lihavainen, H., Leppä, J., Lehtinen, K. E. J., Mirme, A., Mirme, S., Hõrrak, U., Berndt, T., Stratmann, F., Birmili, W., Wiedensohler, A., Metzger, A., Dommen, J., Baltensperger, U., Kiendler-Scharr, A., Mentel, T. F., Wildt, J.,Winkler, P. M., Wagner, P. E., Petzold, A., Minikin, A., Plass-Dülmer, C., Pöschl, U., Laaksonen, A., and Kulmala, M.: Atmospheric nucleation: highlights of the EUCAARI project and future directions, Atmos. Chem. Phys., 10, 10829-10848, doi:10.5194/acp-10-10829-2010, 2010.

Kroll, J. H., Sahay, S. R., Anderson, J. G., Demerjian, K. L., and Donahue, N. M.: Mechanism of HOx formation in the gas-phase ozone-alkene reaction. 2. Prompt versus thermal dissociation of carbonyl oxides to form OH, J. Phys. Chem. A, 105, 4446-4457, 2001.

Kulmala, M., Toivonen, A., Mäkelä, J. M., and Laaksonen, A.: Analysis of the growth of nucleation mode particles observed in Boreal forest, Tellus, 50B, 449-462, 1998.

Kulmala, M., Vehkamäki, H., Petäjä, T., Dal Maso, M., Lauri, A., Kerminen, V.-M., Birmili, W., and McMurry, P. H.: Formation and growth rates of ultrafine atmospheric particles: a review of observations. J. Aerosol Sci., 35, 143-176, 2004.

Kurtén, T., Lane, J. R., Jørgensen, S., and Kjaergaard, H. G.: A computational study of the oxidation of $\mathrm{SO} 2$ to $\mathrm{SO} 3$ by gas-phase organic oxidants, J. Phys. Chem. A, 115, 8669-8681, 2011.

Lelieveld, J., Butler, T. M., Crowley, J. N., Dillon, T. J., Fischer, H., Ganzeveld, L., Harder, H., Lawrence, M. G., Martinez, M., Taraborrelli, D., and Williams, J.: Atmospheric oxidation capacity sustained by a tropical forest, Nature, 452, 737-740, 2008.

Lindinger, W., Hansel, A., and Jordan, A.: On-line monitoring of volatile organic compounds at ppt levels by means of ProtonTransfer Reaction Mass Spectrometry (PTR-MS) Medical application, food control and environmental research, Int. J. Mass Spectrom. Ion Proc., 173, 191-241, 1998.

Lou, S., Holland, F., Rohrer, F., Lu, K., Bohn, B., Brauers, T., Chang, C.C., Fuchs, H., Häseler, R., Kita, K., Kondo, Y., Li, X., Shao, M., Zeng, L., Wahner, A., Zhang, Y., Wang, W., and Hofzumahaus, A.: Atmospheric $\mathrm{OH}$ reactivities in the Pearl River Delta - China in summer 2006: measurement and model results, Atmos. Chem. Phys., 10, 11243-11260, doi:10.5194/acp-10-11243-2010, 2010.

Mauldin III, R. L., Berndt, T., Sipilä, M., Paasonen, P., Petäjä, T., Kim, S., Kurtén, T., Stratmann, F., Kerminen, V.-M., and Kulmala, M.: A new atmospherically relevant oxidant, Nature, 488, 193-196, doi:10.1038/nature11278, 2012.

Neeb, P., Horie, O., and Moortgat, G. K.: The nature of the transitory product in the gas-phase ozonolysis of ethene, Chem. Phys. Lett., 246, 150-156, 1995. 
Neeb, P., Horie, O., and Moortgat, G. K.: Gas-phase ozonolysis of ethene in the presence of hydroxylic compounds, Int. J. Chem. Kinet., 28, 721-730, 1996.

Neeb, P., Sauer, F., Horie, O., and Moortgat, G. K.: Formation of hydroxymethyl hydroperoxide and formic acid in alkene ozonolysis in the presence of water vapour, Atmos. Environ., 31, 1417-1423 1997.

Nölscher, A. C., Williams, J., Sinha, V., Custer, T., Song, W., Johnson, A. M., Axinte, R., Bozem, H., Fischer, H., Pouvesle, N., Phillips, G., Crowley, J. N., Rantala, P., Rinne, J., Kulmala, M., Gonzales, D., Valverde-Canossa, J., Vogel, A., Hoffmann, T., Ouwesloot, H. G., Vila-Guerau de Arellano, J., and Lelieveld, J.: Summertime total $\mathrm{OH}$ reactivity measurements from boreal forest during HUMPPA-COPEC 2010, Atmos. Chem. Phys., 12, 8257-8270, doi:10.5194/acp-12-8257-2012, 2012.

Petäjä, T., Mauldin, III, R. L., Kosciuch, E., McGrath, J., Nieminen, T., Paasonen, P., Boy, M., Adamov, A., Kotiaho, T., and Kulmala, M.: Sulfuric acid and $\mathrm{OH}$ concentrations in a boreal forest site, Atmos. Chem. Phys., 9, 7435-7448, doi:10.5194/acp9-7435-2009, 2009.

Pierce, J. R., Evans, M. J., Scott, C. E., D’Andrea, S. D., Farmer, D. K., Swietlicki, E., and Spracklen, D. V.: Weak global sensitivity of cloud condensation nuclei and the aerosol indirect effect to Criegee $+\mathrm{SO}_{2}$ chemistry, Atmos. Chem. Phys., 13, 3163-3176, doi:10.5194/acp-13-3163-2013, 2013.

Riipinen, I., Sihto, S.-L., Kulmala, M., Arnold, F., Dal Maso, M., Birmili, W., Saarnio, K., Teinilä, K., Kerminen, V.-M., Laaksonen, A., and Lehtinen, K. E. J.: Connections between atmospheric sulphuric acid and new particle formation during QUEST III-IV campaigns in Heidelberg and Hyytiälä, Atmos. Chem. Phys., 7, 1899-1914, doi:10.5194/acp-7-1899-2007, 2007.

Riipinen, I., Pierce, J. R., Yli-Juuti, T., Nieminen, T., Häkkinen, S., Ehn, M., Junninen, H., Lehtipalo, K., Petäjä, T., Slowik, J., Chang, R., Shantz, N. C., Abbatt, J., Leaitch, W. R., Kerminen, V.-M., Worsnop, D. R., Pandis, S. N., Donahue, N. M., and Kulmala, M.: Organic condensation: a vital link connecting aerosol formation to cloud condensation nuclei $(\mathrm{CCN})$ concentrations, Atmos. Chem. Phys., 11, 3865-3878, doi:10.5194/acp-11-38652011, 2011.
Sipilä, M., Berndt, T., Petäjä, T., Brus, D., Vanhanen, J., Stratmann, F., Patokoski, J., Mauldin, R. L., Hyvärinen, A.-P., Lihavainen, H., and Kulmala, M.: The role of sulfuric acid in atmospheric nucleation, Science, 327, 1243-1246, 2010.

Taatjes, C. A., Welz O., Eskola, A. J., Savee, J. D., Osborn, D. L., Lee, E. P., Dyke, J. M., Mok, D. W., Shallcross, D. E., and Percival, C. J.: Direct measurement of Criegee intermediate $\left(\mathrm{CH}_{2} \mathrm{OO}\right)$ reactions with acetone, acetaldehyde, and hexafluoroacetone, Phys. Chem. Chem. Phys., 14, 10391-10400, 2012.

Taatjes, C. A., Welz, O., Eskola, A. J., Savee, J. D., Scheer, A. M., Shallcross, D. E., Rotavera, B., Lee, E. P. F., Dyke, J. M., Mok, D. K. W., Osborn, D. L., and Percival, C. J.: Direct Measurements of Conformer-Dependent Reactivity of the Criegee Intermediate $\mathrm{CH}_{3} \mathrm{CHOO}$, Science, 340, 177-180, 2013.

Taraborrelli, D., Lawrence, M. G., Crowley, J. N., Dillon, T. J., Gromov, S., Groß, C., Vereecken, L., and Lelieveld, J.: Hydroxyl radical buffered by isoprene oxidation over tropical forests, Nature Geosci., 5, 190-193, 2012.

Thamm, J., Wolff, S., Turner, W. V., Gäb, S., Thomas, W., Zabel, F., Fink, E. H., and Becker, K. H.: Proof of the formation of hydroperoxymethyl formate in the ozonolysis of ethene: Synthesis and ft-ir spectra of the authentic compound, Chem. Phys. Lett., 258, 155-158, 1996.

Vereecken, L., Harder, H., and Novelli, A.: The reaction of Criegee intermediates with $\mathrm{NO}, \mathrm{RO}_{2}$, and $\mathrm{SO}_{2}$, and their fate in the atmosphere, Phys. Chem. Chem. Phys., 14, 14682-14695, 2012.

Welz, O., Savee, J. D., Osborn, D. L., Vasu, S. S., Percival, C. J., Shallcross, D. E., and Taatjes, C. A.: Direct Kinetic Measurements of Criegee Intermediate $\left(\mathrm{CH}_{2} \mathrm{OO}\right)$ Formed by Reaction of $\mathrm{CH}_{2} \mathrm{I}$ with $\mathrm{O}_{2}$, Science, 335, 204-207, doi:10.1126/science.1213229, 2012.

Welz, O., Eskola, A. J., Sheps, L., Rotavera, B., Savee, J. D., Scheer, A. M., Osborn, D. L., Lowe, D., Murray Booth, A., Xiao, P., Anwar H., Khan, M., Percival, C. J., Shallcross, D. E., and Taatjes, C. A.: Rate coefficients of C(1) and C(2) Criegee intermediate reactions with formic and acetic Acid near the collision limit: direct kinetics measurements and atmospheric implications, Angew. Chem. Int. Ed. Engl., 53, 4547-4750. doi:10.1002/anie.201400964, 2014. 